\title{
Faktor-Faktor yang Mempengaruhi Minat Menabung di Bank Syariah Surakarta
}

\author{
Ipfa Retno Astuti, Endang Masitoh, Purnama Siddi \\ Universitas Islam Batik Surakarta \\ ipfaretno25@gmail.com
}

\begin{abstract}
This study aims to examine and analyze the effect of religiosity, profit sharing and service on interest in saving at the Surakarta Islamic Bank. The benefits that are expected to increase and provide knowledge related to the influence of religiosity, profit sharing and services on the interest in saving at the Surakarta Islamic Bank, can be used as material for community consideration and Islamic banking management to develop the role of Islamic banking and marketing strategies in Surakarta. The sampling technique was using purposive sampling technique. The population and sample in this study were 71 people who fit the specified criteria. The data were processed using SPSS, the tests carried out included instrument tests, classical assumption tests and multiple linear regression tests. The conclusion in this study is that religiosity has an effect on the interest in saving in Islamic banks in Surakarta. Profit sharing affects the interest in saving in Islamic banks in Surakarta. Services affect the interest in saving at a syariah bank in Surakarta.
\end{abstract}

Keywords- religiosity, sharing, results, service, interest, saving

\begin{abstract}
Abstrak- Penelitian ini bertujuan untuk menguji dan menganalisis pengaruh religiusitas, bagi hasil dan pelayanan terhadap minat menabung di Bank Syariah Surakarta. Manfaat yang diharapkan dapat menambah dan memberikan pengetahuan yang berkaitan dengan pengaruh religiusitas, bagi hasil dan pelayanan terhadap minat menabung di Bank Syariah Surakarta, dapat digunakan sebagai bahan pertimbangan masyarakat dan manajemen perbankan syariah untuk mengembangkan peranan perbankan syariah dan strategi marketing di Kota Surakarta. Teknik pengambilan sampel menggunakan teknik purposive sampling. Populasi dan sampel dalam penelitian ini adalah 71 orang yang sesuai dengan kriteria yang ditentukan. Data diolah menggunakan SPSS , pengujian yang dilakukan meliputi uji instrumen, uji asumsi klasik dan uji regresi linier berganda. Kesimpulan dalam penelitian ini adalah religiusitas berpengaruh terhadap minat menabung di bank syariah surakarta. Bagi hasil berpengaruh terhadap minat menabung di bank syariah surakarta. Pelayanan berpengaruh terhadap minat menabung di bank syariah surakarta.
\end{abstract}

Kata Kunci- religiusitas, bagi, hasil, pelayanan, minat, menabung

\section{PENDAHULUAN}

Perhatian masyarakat terhadap perbankan selalu besar, baik pada saat ekonomi sedang tumbuh subur, maupun sebaliknya. Hal itu dikarenakan lembaga perbankan dalam kehidupan dunia modern merupakan suatu lembaga yang sulit dihindari. Perkembangan industri perbankan di Indonesia pasca deregulasi perbankan tahun 1988 mengakibatkan peran perbankan sebagai lembaga financial intermediary dalam membiayai external financing terutama untuk investasi semakin bertambah . Jumlah bank meningkat dua kali lipat selama sepuluh tahun yaitu dari 111 bank pada tahun 1988 menjadi 237 bank pada tahun 1997 (sebelum krisis) dan jumlah kantor bank juga mengalami peningkatan lebih dari $200 \%$ pada tahun yang sama (Maysun, 2005: 6).

Memasuki tahun pertengahan 1997 terjadi krisis moneter yang melanda negara-negara asia. Akan tetapi, dalam keterpurukan tersebut masih ada perbankan syariah yang tetap bertahan dengan menggunakan prinsip bagi hasil yang berdasar pada syariat islam. Perbankan tersebut ialah Bank Syariah Indonesia (BMI), bank syariah pertama di Indonesia yang tidak terkena negative spread pada saat krisis. Negative spread adalah pendapatan bunga negatif, padahal pendapatan bunga merupakan sumber pendapatan terbesar bank konvensional yang dalam situasi normal di Indonesia mencakup 65\%-80\% dari total pendapatan [1]. Bank Syariah dapat bertahan karena tidak memasukkan variabel bunga atau riba yang dilarang agama Islam, melainkan menerapkan prinsip bagi hasil dalam sistem transaksinya [2].

Dalam penelitian yang dilakukan oleh Sisca Damayanti (2016) menyatakan bahwa pandangan islam, pelayanan dan keamanan berpengaruh positif terhadap minat menabung di bank syariah mandiri cabang X. Penelitian yang dilakukan oleh Wirdayani Wahab (2016) menyatakan bahwa tingkat bagi hasil berpengaruh secara signifikan terhadap minat menabung nasabah. Hasil temuan ini karena tingkat bagi hasil adalah hal yang begitu dominan dalam mndorong seseorang nasabah dalam membuka rekening tabungan di bank syariah. Penelitian oleh Siti Maisharah Amanda (2019) menyatakan bahwa pengetahuan, pendapatan, lokasi, produk, dan pelayanan mempengaruhi minat menabung di bank 
syariah. Berdasarkan uraian diatas, maka penulis membahas "Faktor-Faktor Yang Mempengaruhi Minat Menabung Di Bank Syariah Surakarta". Tujuan dalam penelitian adalah (1) Untuk mengetahui bagaimana pengaruh religiusitas terhadap minat menabung di Bank Syariah Surakarta. (2) Untuk mengetahui bagaimana pengaruh bagi hasil terhadap minat menabung di Bank Syariah Surakarta. (3) Untuk mengetahui bagaimana pengaruh pelayanan terhadap minat menabung di Bank Syariah Surakarta.

\section{Konsep Dasar}

\section{KAJIAN PUSTAKA}

Dalil-dalil yang Mengharamkan Riba dari $\mathrm{Al}$ qur'an dalam surat An-Nisaa, dalam surat Ali Imran Allah Subhanahu wa ta'ala berfirman: "Hai orangorang yang beriman, janganlah kamu memakan Riba dengan berlipat ganda dan bertakwalah kamu kepada Allah supaya kamu mendapat keberuntungan." (QS. Ali Imraan: 130).

Dalil yang Mengharamkan Riba dari Hadits, Diriwayatkan oleh Bukhari "Rasulullah melaknat pemakan riba, orang yang memberi makan dengan riba, juru tulis transaksi riba, dua orang saksinya, semuanya sama saja."(HR.Bukhari fathul bari/V:4/H:394/bab:24)

Kaum muslimin seluruhnya telah bersepakat bahwa asal dari riba adalah diharamkan, terutama sekali riba pinjaman atau hutang. Bahkan mereka telah bersepakat dalam hal itu pada setiap masa dan tempat. Para ulama Ahli Fikih seluruh madzhab telah menukil ijma' tersebut. Memang ada perbedaan pendapat tentang sebagian bentuk masalahnya, apakah termasuk riba atau tidak dari segi praktisnya, namun tidak bertentangan dengan asal ijma' yang telah diputuskan dalam persoalan itu. Ijma' akan pengharamannya dinukilkan dari An Nawawi dalam Al Majmu' Syarhul Muhadzab 9/391, dan Ibnu Taimiyah dalam Majmu' Al fatawa 29/419. Pengharaman Riba tidak terbatas hanya pada syari'at islam bahkan juga ada dalam syari'at agama sebelumnya.

\section{Minat menabung}

Secara etimologi pengertian minat adalah perhatian, kesukaan (kecenderungan hati) kepada sesuatu keinginan. Minat adalah perpaduan antara keinginan dan kemauan yang dapat berkembang. Minat merupakan salah satu faktor yang cukup penting dalam mempengaruhi preferensi calon nasabah dalam menabung (Iskandarwasid \& Sunendar, 2011). Sedangkan menabung sendiri adalah tindakan yang dianjurkan oleh islam, karena dengan menabung berarti seorang muslim mempersiapkan diri untuk pelaksanaan masa yang akan datang sekaligus untuk menghadapi hal-hal yanng tak diinginkan (Umam, 2016). Dapat disimpulkan bahwa minat menabung adalah keinginan yang timbul dari diri sendiri tanpa ada paksaan dari orang lain untuk menyisihkan sebagian uang yang dimiliki untuk disimpan

\section{Religiusitas}

Religius menurut Islam adalah menjalankan ajaran agama secara menyeluruh. Allah berfirman dalam Al-Qur'an surat Al-Baqarah ayat 208: Artinya: "hai orang-orang yang beriman, masuklah kamu kedalam Islam keseluruhan, dan janganlah kamu turut langkah-langkah syaitan. Sesungguhnya syaitan itu adalah musuh yang nyata bagimu". Dapat disimpulkan bahwa religiusitas adalah ketaatan seseorang dalam meyakini suatu agama yang diwujudkan dalam bertingkah laku, bersikap dan bertindak sesuai dengan ajaran agama dalam kehidupan sehari-hari.

\section{Bagi hasil}

Bagi hasil adalah suatu sistem yang meliputi tata cara pembagian hasil usaha antara penyedia dana dan pengelola dana (Rofiq, 2004). Jika bank konvensional membayar bunga kepada nasabahnya, maka bank syariah membayar bagi hasil atas keuntungan sesuai dengan kesepakatan. Kesepakatan ini ditetapkan dengan suatu angka tingkat rasio bagi hasil atau nisbah.

\section{Pelayanan}

Pelayanan atau jasa (service) adalah suatu hasil (product) dari kegiatan hubungan timbal balik antara producer dan costumer dengan melalui beberapa kegiatan internal, producer dapat memenuhi kebutuhan costumer dalam bentuk kepuasan (satisfaction) (H \& Yoeti, 1995). Sehingga dapat disimpulkan bahwa pelayanan adalah suatu kegiatan yang terjadi dalam interaksi langsung maupun tidak langsung antara seseorang dengan orang lain serta menyediakan kepuasan orang lain.

\section{Penelitian sebelumnya}

Dalam penelitian yang dilakukan oleh Sisca Damayanti, 2016 menyatakan bahwa pandangan islam, pelayanan dan keamanan berpengaruh positif terhadap minat menabung di bank syariah mandiri cabang X. Penelitian yang dilakukan oleh Wirdayani Wahab (2016) menyatakan bahwa tingkat bagi hasil berpengaruh secara signifikan terhadap minat menabung nasabah. Hasil temuan ini karena tingkat bagi hasil adalah hal yang begitu dominan dalam mndorong seseorang nasabah dalam membuka rekening tabungan di bank syariah. Penelitian oleh Siti Maisharah Amanda (2019) menyatakan bahwa pengetahuan, pendapatan, lokasi, produk, dan 
pelayanan mempengaruhi minat menabung di bank syariah.

\section{Kerangka berpikir dan hipotesis}

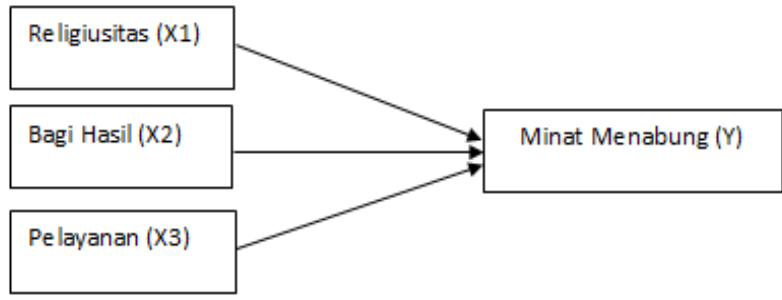

Gambar 1.1

1. Pengaruh religiusitas terhadap minat menabung di bank syariah Surakarta

Penelitian oleh (Igayani, 2018) yang meneliti tentang faktor-faktor yang mempengaruhi minat menabung di bank syariah dengan studi kasus mahasiswa akuntansi universitas nusantara PGRI Kediri. Hasil dari penelitian menunjukkan bahwa religiusitas berpengaruh terhadap minat menabung mahasiswa akuntansi universitas nusantara PGRI Kediri 2018 di bank syariah. Dengan semakin paham seseorang mengenai dosa riba, maka akan membuat seseorang tersebut menjauhi riba, sehingga beralih pada bank syariah.

H1: Religiusitas berpengaruh terhadap minat menabung di bank syariah Surakarta

2. Pengaruh bagi hasil terhadap minat menabung di bank Syariah Surakarta

Penelitian oleh (Wahab, 2016) yang meneliti pengaruh tingkat bagi hasil terhadap minat menabung di bank syariah. Hasil penelitian menemukan bahwa antara tingkat bagi hasil dengan minat menabung nasabah memiliki hubungan yang sangat kuat. Dari uji F menunjukkan bahwa tingkat bagi hasil mempunyai pengaruh yang signifikan terhadap minat menabung nasabah. Dengan maksud lain antar tingkat bagi hasil dengan minat menabung nasabah memiliki pengaruh yang kuat. Semakin besar bagi hasil yang diberikan oleh bank syariah, maka akan semakin besar minat nasabah untuk menabung di bank syariah.

$\mathrm{H} 2$ : Bagi hasil berpengaruh terhadap minat menabung di bank syariah surakarta

3. Pengaruh pelayanan terhadap minat menabung di bank Syariah Surakarta

Penelitian oleh (Amanda, 2019) yang meneliti tentang faktor-faktor yang mempengaruhi minat menabung di bank syariah studi kasus dosen universitas syiah kuala. Hasil penelitian menunjukkan bahwa pelayanan memiliki pengaruh yang signifikan terhadap minat menabung di bank syariah. Dengan kualitas pelayanan yang baik maka akan membuat nasabah merasa nyaman, sehingga bisa meningkatkan minat menabung di bank syariah.

H3: Pelayanan berpengaruh terhadap minat menabung di bank syariah Surakarta

\section{METODE PENELITIAN}

Jenis penelitian ini adalah penelitian kualitatif dengan data primer. Instrumen penelitian berupa kuesioner yang dibagikan kepada responden. Untuk respondennya sendiri adalah orang yang sesuai dengan kriteria yang telah ditentukan. Pengambilan sampel dilakukan menggunakan teknik purposive sampling. Populasi dan sample dalam penelitian ini adalah masyarakat surakarta yang belum memilki rekening bank syariah dan berminat untuk memiliki rekening bank syariah. Teknik pengumpulan data dengan cara penyebaran kuisoner secara online menggunakan social media. Data yang telah terkumpul diolah menggunakan SPSS 20. Pengujian yang dilakukan meliputi uji instrumen, uji asumsi klasik, dan uji regresi linier berganda. Variabel dependen dalam penelitian ini adalah minat menabung di bank syariah surakarta, sedangkan variabel independen nya adalah religiusitas, bagi hasil dan pelayanan. Pengukuran variabel menggunakan skala Likert.

\section{HASIL DAN PEMBAHASAN}

\section{Uji Normalitas}

Tabel 1.1 Hasil Uji Normalitas

\begin{tabular}{llll}
\hline $\begin{array}{l}\text { Kolmogorov- } \\
\text { Smirnov } Z\end{array}$ & $\begin{array}{l}\text { Asymp. Sig. } \\
\text { (2-tailed) }\end{array}$ & Batas & Keterangan \\
\hline 0,069 & 0,200 & 0,05 & Normal \\
\hline
\end{tabular}

Sumber : Data diolah, 2020

Berdasarkan tabel 4.12 diatas menjelaskan bahwa uji normalitas Kolmogorov-Smirnov $Z$ yang merupakan bagian dari uji asumsi klasik. Dimana uji normalitas bisa dikatakan residualnya berdistribusi normal apabila nilai signifikansi $>0,05$, sebaliknya jika nilai signifikansi < 0,05 maka nilai residual tidak berdistribusi normal. Dari tabel 4.12 diatas menunjukkan bahwa nilai signifikansi sebesar 0,200> 0,05 yang berarti residualnya berdistribusi normal. 


\section{Uji Multikolinearitas}

Tabel 1.2 Hasil Uji Multikolinearitas

\begin{tabular}{|c|c|c|c|c|c|}
\hline Variabel & Tolerance & Std & $V I F$ & Std & Ket. \\
\hline $\begin{array}{l}\text { Religiusitas } \\
\left(\mathrm{X}_{1}\right)\end{array}$ & 0,722 & $\begin{array}{c}> \\
0,1 \\
0\end{array}$ & $\begin{array}{c}1,38 \\
4\end{array}$ & $<10$ & $\begin{array}{l}\text { Tidak Ada } \\
\text { Multikolin } \\
\text { earitas }\end{array}$ \\
\hline $\begin{array}{l}\text { Bagi } \\
\text { hasil }\left(X_{2}\right)\end{array}$ & 0,809 & $\begin{array}{c}> \\
0,1 \\
0\end{array}$ & $\begin{array}{c}1,23 \\
7\end{array}$ & $<10$ & $\begin{array}{l}\text { Tidak Ada } \\
\text { Multikolin } \\
\text { earitas }\end{array}$ \\
\hline $\begin{array}{l}\text { Pelayanan } \\
\left(\mathrm{X}_{3}\right)\end{array}$ & 0,705 & $\begin{array}{c}> \\
0,1 \\
0\end{array}$ & $\begin{array}{c}1,41 \\
9\end{array}$ & $<10$ & $\begin{array}{l}\text { Tidak Ada } \\
\text { Multikolin } \\
\text { earitas }\end{array}$ \\
\hline
\end{tabular}

Sumber : Data diolah, 2020

Berdasarkan tabel 4.13 diatas diketahui bahwa ketiga variabel mempunyai nilai Tolerance > 0,10 dan VIF < 10 , yang artinya tidak terjadi multikolinearitas antar variabel bebas (independen). Sehingga dalam model regresi ini lolos uji multikolinearitas.

\section{Uji Heteroskedastisitas}

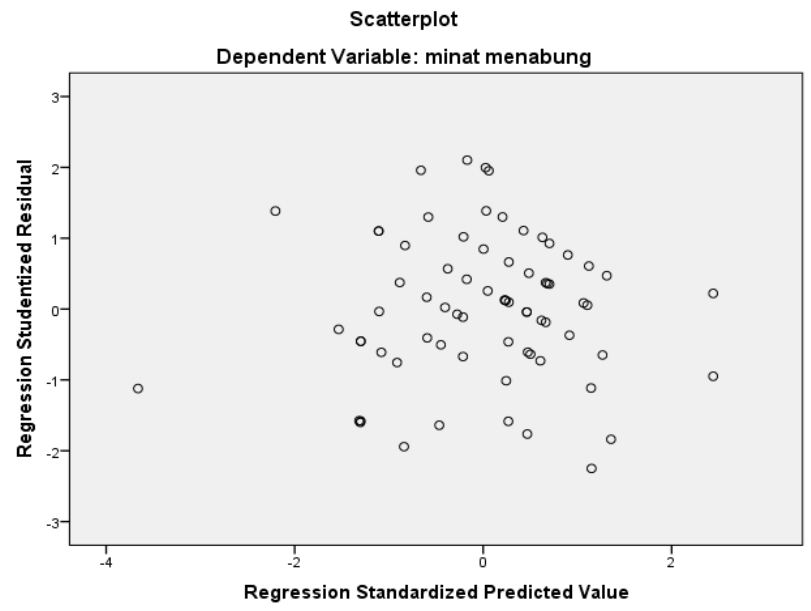

Gambar 1.2 Hasil Uji Heteroskedastisitas

Berdasarkan gambar diatas disimpulkan bahwa titiktitik tidak membentuk pola yang jelas, dan menyebar di atas dan di bawah angka 0 pada sumbu $\mathrm{Y}$ sehingga tidak terjadi masalah heterokesdatisitas pada model regresi.

\section{Uji Regresi Linier Berganda}

Model Regresi

Tabel 1.3 Hasil Uji Regresi Linear Berganda

\begin{tabular}{lcc}
\hline \multicolumn{1}{c}{ Variabel } & $\mathrm{B}$ & Std. Error \\
\hline (Constant $)$ & 1,881 & 1,647 \\
Religiusitas $\left(\mathrm{X}_{1}\right)$ & 0,281 & 0,134 \\
Bagi hasil $\left(\mathrm{X}_{2}\right)$ & 0,302 & 0,126 \\
Pelayanan $\left(\mathrm{X}_{3}\right)$ & 0,266 & 0,128 \\
\hline
\end{tabular}

Sumber: Data diolah, 2020
Berdasarkan tabel 4.14 dapat dirumuskan persamaan regresi linear berganda sebagai berikut :

$Y=1.881+0.281 X_{1}+0.302 X_{2}+0.266 X_{3}+e$

Dari persamaan regresi diatas berikut ini adalah hasil penjelasannya :

Nilai konstanta sebesar 1,881 menyatakan bahwa jika variabel religiusitas, bagi hasil, dan pelayanan bernilai 0 maka nilai minat menabung di bank syariah surakarta sebesar 1,881. Koefisien religiusitas $\left(\mathrm{X}_{1}\right)$ bernilai positif sebesar 0,281 menyatakan bahwa jika religiusitas $\left(\mathrm{X}_{1}\right)$ naik sebesar 1 satuan dengan asumsi variabel lainnya tetap, maka minat menabung meningkat sebesar 0,281 . Koefisien bagi hasil $\left(\mathrm{X}_{2}\right)$ bernilai positif sebesar 0.302 menyatakan bahwa jika bagi hasil $\left(\mathrm{X}_{2}\right)$ naik sebesar 1 satuan maka minat menabung bertambah sebesar 0.302. Dengan asumsi tidak ada penambahan (konstan) variabel lainnya. Koefisien pelayanan $\left(\mathrm{X}_{3}\right)$ bernilai positif sebesar 0.266 menyatakan bahwa jika pelayanan $\left(\mathrm{X}_{3}\right)$ naik sebesar 1 satuan maka minat menabung bertambah sebesar 0.266 . Dengan asumsi tidak ada penambahan (konstan) variabel lainnya.

Uji Kelayakan Model (Uji F)

Tabel 1.4 Hasil Uji F

\begin{tabular}{cccc}
\hline Model & F tabel & F hitung & Keterangan \\
\hline 1 & 2,742 & 11,806 & Ha diterima \\
\hline
\end{tabular}

Sumber : Data diolah, 2020

Berdasarkan hasil analisis uji $\mathrm{F}$ dengan program SPSS, Ha diterima apabila $F_{\text {hitung }}<F_{\text {tabel }}$, Ho ditolak apabila $F_{\text {hitung }}>F_{\text {tabel. }}$. Dari output diperoleh hasil $F_{\text {hitung }}$ sebesar 11,806 sedangkan $\mathrm{F}_{\text {tabel }}$ sebesar 2,742 dan signifikansi $0,000<0,05$ maka Ha diterima. Dapat disimpulkan bahwa ada pengaruh secara simultan antara variabel religiusitas $\left(\mathrm{X}_{1}\right)$, bagi hasil $\left(\mathrm{X}_{2}\right)$ dan pelayanan $\left(\mathrm{X}_{3}\right)$ terhadap minat menabung pada Bank Syariah Surakarta.

\section{Uji Hipotesis (Uji t)}

Tabel 1.5 Hasil Uji t

\begin{tabular}{|c|c|c|c|c|c|}
\hline Variabel & thitung & $t_{\text {tabel }}$ & Sig & stand & Keterangan \\
\hline $\begin{array}{l}\text { Religiusitas } \\
\left(\mathrm{X}_{1}\right)\end{array}$ & 2,093 & 1,668 & 0,040 & $\begin{array}{c}< \\
0,05\end{array}$ & $\begin{array}{c}\mathrm{Ha} \\
\text { diterima }\end{array}$ \\
\hline $\begin{array}{l}\text { Bagi hasil } \\
\left(\mathrm{X}_{2}\right)\end{array}$ & 2,405 & 1,668 & 0,019 & $\stackrel{<}{<, 05}$ & $\begin{array}{c}\mathrm{Ha} \\
\text { diterima }\end{array}$ \\
\hline $\begin{array}{l}\text { Pelayanan } \\
\left(\mathrm{X}_{3}\right)\end{array}$ & 2,086 & 1.668 & 0,041 & $<$ & $\begin{array}{c}\mathrm{Ha} \\
\text { diterima }\end{array}$ \\
\hline
\end{tabular}

Sumber : Data diolah, 2020

Berdasarkan perhitungan diatas diperoleh hasil thitung $(2,093) \geq t_{\text {tabel }}(1,668)$ dan niliai signifikansi $0,040<$ 0,05 sehingga Ho ditolak. Maka dapat disimpulkan bahwa variabel religiusitas secara parsial berpengaruh 
positif dan signifikan terhadap Minat menabung pada Bank Syariah Surakarta.

Berdasarkan perhitungan diatas diperoleh hasil thitung $(2,405) \geq t_{\text {tabel }}(1,668)$ dan niliai signifikansi $0,019<$ 0,05 sehingga Ho ditolak. Maka dapat disimpulkan bahwa variabel bagi hasil secara parsial berpengaruh positif dan signifikan terhadap Minat menabung pada Bank Syariah Surakarta.

Berdasarkan perhitungan diatas diperoleh hasil thitung $(2,086) \leq t_{\text {tabel }}(1,668)$ dan niliai signifikansi $0,041>$ 0,05 sehingga Ho ditolak. Maka dapat disimpulkan bahwa variabel pelayanan secara parsial berpengaruh positif terhadap Minat menabung pada Bank Syariah Surakarta.

\section{Koefisien Determinasi $\left(R^{2}\right)$}

Tabel 1.6 Hasil Uji Koefisien Determinasi

\begin{tabular}{cccc}
\hline Model & $\mathrm{R}$ & $\begin{array}{c}\text { Adjust } \mathrm{R} \\
\text { Square }\end{array}$ & Keterangan \\
\hline 1 & 0,588 & 0,317 & Berpengaruh 31,7\% \\
\hline
\end{tabular}

Sumber : Data diolah, 2020

Berdasarkan tabel perhitungan diatas diperoleh hasil Adjuted $R^{2}$ sebesar 0,317 atau $31,7 \%$. Artinya proporsi variabel dependen yang dijelaskan (religiusitas, bagi hasil, pelayanan) sebesar $31,7 \%$ sedangkan $68,3 \%$ dijelaskan oleh variabel lain yang tidak dijelaskan dalam penelitian ini, misalnya usia, pendidikan, pekerjaan, lokasi dll.

\section{Pembahasan}

1. Pengaruh religiusitas terhadap minat menabung di Bank Syariah Surakarta.

Pengaruh religiusitas terhadap minat menabung mempunyai nilai t hitung sebesar 2.093 dengan nilai probabilitas sebesar 0.040 . Nilai probabilitas $=0.040<\alpha=0.05$. Hal ini berarti religiusitas berpengaruh signifikan terhadap minat menabung. Berdasarkan penjelasan tersebut maka hipotesis 1 religiusitas berpengaruh terhadap minat menabung di Bank Syariah Surakarta diterima.

2. Pengaruh bagi hasil terhadap minat menabung minat menabung di Bank Syariah Surakarta

Pengaruh bagi hasil terhadap minat menabung mempunyai nilai t hitung sebesar 2.405 dengan nilai probabilitas sebesar 0.019 . Nilai probabilitas $=0.019<\alpha=0.05$. Hal ini berarti bagi hasil berpengaruh signifikan terhadap minat menabung. Berdasarkan penjelasan tersebut maka hipotesis 2 bagi hasil berpengaruh terhadap minat menabung di Bank Syariah Surakarta diterima.
3. pengaruh pelayanan terhadap minat menabung Pengaruh pelayanan terhadap minat menabung mempunyai nilai t hitung sebesar 2.086 dengan nilai probabilitas sebesar 0.041 . Nilai probabilitas $=0.041<\alpha=0.05$. Hal ini berarti pelayanan berpengaruh signifikan terhadap minat menabung. Berdasarkan penjelasan tersebut maka hipotesis 3 pelayanan berpengaruh terhadap minat menabung di Bank Syariah Surakarta diterima

\section{KESIMPULAN DAN SARAN}

Penelitian ini bertujuan untuk menguji dan menganalisis pengaruh religiusitas, bagi hasil dan pelayanan terhadap minat menabung di Bank Syariah Surakarta. Populasi dalam penelitian ini yaitu masyarakat surakarta yang belum memiliki rekening di bank syariah dan memiliki minat untuk menabung di bank syariah surakarta, dengan jumlah responden sebanyak 71. Teknik pengambilan sample menggunakan metode purposive sampling dan melalui uji analisis regresi berganda. Berdasarkan pengujian hipotesis yang dilakukan pada penelitian ini dapat disimpulkan bahwa religiusitas berpengaruh terhadap minat menabung di bank syariah surakarta. Bagi hasil berpengaruh terhadap minat menabung di bank syariah surakarta. Pelayanan berpengaruh terhadap minat menabung di bank syariah surakarta.

Keterbatasan dalam Penelitian ini yaitu Keterbatasan penyebaran kuesioner yang kurang menyeluruh di kecamatan yang ada di kota Surakarta dikarenakan penyebaran kuesioner hanya dengan sosial media. Penelitian ini hanya menggunakan beberapa variabel yang mempengaruhi minat menabung yaitu religiusitas, bagi hasil dan pelayanan, sedangkan masih 68,3\% dipengaruhi oleh faktor lain yang tidak diteliti dalam penelitian ini. Keterbatasan pernyataan yang hanya menggunakan beberapa item per variabel yang mungkin masih kurang dalam memahami permasalahan secara menyeluruh. Berdasarkan keterbatasan yang melekat pada penelitian ini, saran bagi peneliti selanjutnya adalah Bagi penelitian selanjutnya diharapkan mampu menambah variabel- variabel lain yang dapat mempengaruhi minat menabung. Diharapkan menyebarkan kuesioner secara menyeluruh di semua kecamatan yang ada di kota surakarta sehingga hasil bisa lebih mewakili kota surakarta. Diharapkan menggunakan lebih banyak pernyataan per variabel sehingga dapat memahami permasalahan secara menyeluruh. 


\section{REFERENSI}

[1] I. S. Putri and Y. Tdkw, "Pengaruh Struktur Kepemilikan dan Dewan Komisaris Terhadap Tingkat Pengungkapan Risiko pada Bank Syariah," BIEJ Bus. Innov. Entrep. J., vol. 2, no. 1, pp. 41-47, 2020.

[2] N. A. Hamdani and G. A. F. Maulani, "Analysis of Marketing of Sharia Banking Service Products Based on Consumer Perception," no. January 2017, pp. 515-520, 2018, doi: $10.5220 / 0007085005150520$.

[3] Aisyah, M. (2018). Islamic Bank Service Quality and Its Impact on Indonesian Customers' Satisfaction and Loyalty. Journal of Islamic Economics.

[4] Amanda, S. M. (2019). Faktor-Faktor yang Mempengaruhi Minat Menabung di Bank Syariah Studi Kasus Dosen Universitas Syiah Kuala.

[5] Damayanti, S. (2016). Pengaruh Pandangan Islam, Pelayanan dan Keamanan Terhadap Minat Nasabah Untuk Menabung di Bank Syariah Mandiri Cabang X.

[6] H, O. A., \& Yoeti. (1995). Hotel Marketing. Jakarta: Perca.

[7] Igayani, R. Y. (2018). Faktor-Faktor yang Mempengaruhi Minat Menabung di Bank Syariah.
[8] Iskandarwasid, \& Sunendar, D. (2011). Strategi Pembelajaran Bahasa. Bandung: Rosda, Cet. Ke 3.

[9] Maysun. (2005). Analisis Kinerja Bank Umum Syariah dan Bank Umum Konvensional di Indonesia. Skripsi FE UNS.

[10] Munthe, S. (2014). Faktor-Faktor Yang Mempengaruhi Minat Nasabah Menabung Pada Tabungan Mudharabah Di Bank Muamalat Cabang Balai Kota.

[11] Pratiwi, A. N. (2010). Analisis Faktor-Faktor yang Mempengaruhi Keputusan Masyarakat Muslim Untuk Menggunakan Bank Syariah.

[12] Rauf, H. A. (2019). Al Qur'an Al Hafidz. Bandung: Cordoba.

[13] Rofiq, A. (2004). Fiqih Kontekstual dari Normatif ke Pemaknaan Soaial. Yogyakarta: Pustaka Pelajar.

[14] Umam, K. (2016). Perbankan Syariah: Dasardasar dan Dinamika Perkembangannya di Indonesia. Jakarta: PT Raja Grafindo Persada.

[15] Wahab, W. (2016). Pengaruh Tingkat Bagi Hasil Terhadap Minat Menabung di Bank Syariah. 